\title{
The Allelopathic Potential of Foliar Application of Aqueous Extracts of Chickpea on Growth and Yield of Chickpea
}

\author{
Kawa A. Ali ${ }^{1 *}$, Kawa K. Miran² \\ ${ }^{1}$ Department of Medical Laboratory Techniques, Erbil Technical Health College, Erbil Polytechinc University, Erbil, Kurdistan Region, Iraq, \\ ${ }^{2}$ Department of Field Crops, College of Agricultural Engineering Sciences, Salahaddin University, Erbil, Kurdistan Region, Iraq
}

\author{
${ }^{*}$ Corresponding author: \\ Kawa A. Ali, Department \\ of Medical Laboratory \\ Techniques, Erbil Technical \\ Health College, Erbil \\ Polytechinc University, Erbil, \\ Kurdistan Region, Iraq. \\ E-mail: kawa.ali@su.edu.krd \\ Received: 14 February 2021 \\ Accepted: 20 June 2021 \\ Published: 30 December 2021 \\ DOI \\ 10.25156/ptj.v11n2y2021.pp7-11
}

\begin{abstract}
A B S T R A C T
A pot experiment was executed in the college of science, Salahaddin university glass house to investigate the allelopathic potentiality of aqueous chickpea Cicer arietinum L. seed extracts that was foliar sprayed on chickpea plants 45 days after sowing to estimate growth, yield, yield components, and seeds chemical characteristics. Results showed that the allelopathic effect was significant on chickpea plant height, number of pods per plant, seeds per pod, shoot dry weight, seed yield per plant, biological yield per plant, harvest index, hundred seeds weight, nitrogen, protein, and phosphorus content. The allelopathic effect was on its own species, and the effect was percentage dependent which, means increasing extract percentage elevated allelopathic impact. The allelopathic index was at the maximum level when the plants were sprayed with the highest extract percentage.
\end{abstract}

Keywords: Allelopathy, Aqueous extract, Concentration-dependent, Seed quality

\section{INTRODUCTION}

Allelopathy is an ecological phenomenon that occurs when an organism, especially plant produces a biochemical compound that influences organisms in the vicinity, in case of plants it affects positively or negatively germination, growth, and survival of neighboring plants (Duke, 2003). These biochemicals are known as allelochemicals, which are secondary plant metabolites biosynthesized from carbohydrate metabolism or through shikimic acid pathway, they are kept inside the plant cell till they are transferred into the environment by leaching, root exudates, volatilization, and residue decomposition to inhibit or stimulate the target (recipient) organisms (Einhellig, 1995). Chickpea (Cicer arietinum L.) from the Fabaceae family is the third most cultivated leguminous crop in the world after bean and pea, second in Iraq after bean, Chickpea is an annual indeterminate long-day flowering plant that adapted to different climates, it grows better in spring sowing dates comparing to winter sowing dates due to mild weather and resistance to semi-arid and arid environments (Joshi et al., 2001). There are two types of chickpea; the first is desi type characterized with small angular or wrinkled brown to fawn-colored seeds, and the second Kabuli type large rounded white colored seeds. More than $80 \%$ of the world production is of desi types, but the number of countries producing Kabuli types is approximately double than countries producing desi type (Khalil et al., 2007). Total chickpea carbohydrates range between $41 \%$ and $47 \%$, while crude protein content could reach $21.7-23.4 \%$, Crude fiber which, located within the seed coat could reach $5 \%$. Chickpea seed protein was found, to be of higher nutritive value than those of other pulse grains (El-Adawy, 2002). Chickpeas meet adult human requirements for all essential amino acids except methionine and cysteine, with a low level of tryptophan besides that it has a high protein digestibility and higher amounts of phosphorus and calcium comparing to other pulses (Wood and Grusak, 2007). Theophrastus, "the father of Botany," who in 300 B.C. wrote in his botanical works about how chickpea "exhausted" the soil and wrecked weeds (Mushtaq et al., 2020). Cato the Elder (234-140 B.C.) documented in his book on how chickpea and barley "scorch up" corn land, he also mentioned the harmful effects of walnut trees on different plants (Liu et al., 2008). It was reported that chickpea root exudation has different chemical compounds mainly benzaldehyde identified as the allelochemical with a stronger negative impact on studied crops than chickpea itself (Chai et al., 2005; Chaichi and Edalati-Fard, 2005) reported that allelopathic potential of chickpea root extracts are dependent on chickpea cultivar and the genetic susceptibility of the recipient studied plant 
(soybean, sorghum, and sunflower). In a study of the mutual effect of Chickpea and wheat aqueous extracts on each other's germination, growth, and seedlings chemical components, it was hypothesized that the chickpea extracts stimulate germination in low concentration $25 \%$ while it starts to inhibit wheat germination and quality in higher concentrations above $50 \%$, so it was concluded that chickpea is allelopathicaly stronger than wheat when compared to each other and the effect is concentration dependent (Yasmin et al., 1999). In a comparative allelopathic study between desi and Kabuli chickpea seed extracts effect on four plant species such as common vetch (Vicia sativa L.), wild narbon vetch (Vicia narbonensis L.), wild mustard (Sinapis arvensis L.), and Kabuli Chickpea (C. arietinum L.), the study outcome indicated the high allelopathic potentiality of both chickpea type and the effect was concertation dependent (Ashti et al., 2018). The goal of this study is to investigate the effect of chickpea aqueous extracts foliar application on the growth, yield, and chemical characteristics of chickpea plants.

\section{MATERIALS AND METHODS}

This study was conducted in botanical garden and laboratories of the biology department, college of Science, Salahaddin University. It consists of five percentage levels $(0,25 \%, 50 \%, 75 \%$, and $100 \%)$ with three replications that arranged in a completely randomized design. The study was conducted in pots to eliminate any intra and intercompetition effects.

\section{Extract Preparation}

Kabuli chickpea seeds were received from the Erbil Research Directorate, first of all, chickpea seeds were milled by electrical mill, then $200 \mathrm{~g}$ of chickpea seeds and $1000 \mathrm{ml}$ of distilled water were put in dark bottles, next the bottles were placed in a shaker 120 round/min (RPM) for $24 \mathrm{~h}$. Then, the aqueous solutions passed through four layers of cheese cloth after that it was filtered by Whatman filter paper \#1. Finally, from the crud extract, different percentages were prepared as $0,25,50,75$, and $100 \%$ by adding distilled water, while distilled water $(0 \%)$ was considered as control treatment.

\section{Cultural Practices}

Plastic pots with a capacity of $5 \mathrm{~kg}$ were filled with soil brought from Aski-Kalak the soil texture was sandy loam, $\mathrm{pH} 7.80$, organic matter $1.72 \%$, electrical conductivity $0.61 \mathrm{ds} . \mathrm{m}^{-1}$, nitrogen $2.21 \%$, phosphorus $1.81 \%$, and potassium $2.1 \%$ passed from $2 \mathrm{~mm}$ sieves. Seven chickpea seeds were planted in $5 \mathrm{~cm}$ depth in each pot on the March 19, 2017. After 20 days from sowing, the germinated seedlings were thinned to two homogenized chickpea plants per pot. Fertilizers were added at the recommended doses for chickpea in Iraq (40 kg nitrogen. ha ${ }^{-1}$ ) and diammonium phosphate $40 \mathrm{~kg}$. ha ${ }^{-1}$ (Al-Taee and Al-Nori, 2015), irrigation of pots were done based on the field capacity indicator which has been provided as a special pot containing the same number of plants without any treatment. Starting from the $1^{\text {st }}$ of May total chlorophylls were estimated weekly by using at LEAF instrument (Zhu et al., 2012). Finally, plants were harvested on the June 17, 2017.

\section{Foliar Extract Spray}

A calibration test was done to ensure the equity of spray amount for each pot to avoid extreme extract spraying (Doruchowski et al., 2012). Five hand sprayers were used each for a percentage level to avoid contamination. First spray process was conducted on the May 3, 2017, second spray on the May 4, 2017, final and third spray on the May 5, 2017. The spray process conducted at evening to avoid high temperatures and it must cover all plant parts. A surfactant tween 20 was mixed with the liquid of all percentage levels to extend the period and surface of liquid interaction to chickpea leaves (Larew et al., 1985).

\section{Recorded Data}

Recorded parameters of chickpea were plant height $(\mathrm{cm})$; brunch number per plant, pods number per plant, seed yield per plant, straw yield per plant, biological yield per plant, and harvest index (equation-1) (Hay, 1995). Seed chemical content nitrogen, phosphorus, potassium, and protein were estimated according to (Allen et al., 1974). Finally, the allelopathic index was estimated according to equation (2) (Ali, 2020).

$$
\begin{aligned}
& \text { Harvest Index }=\left(\frac{\text { Seed Yield }}{\text { Biological Yield }}\right) \times 100 \\
& \mathrm{AI}=\left(1-\frac{\text { SDWt }}{\text { SDWc }}\right) \times 100
\end{aligned}
$$

\section{Data Analysis}

All recorded data were subjected to standard analysis of variance and means were compared using Duncan Multiple Range Test at $5 \%$ of probability using Statistical Package for the Social Sciences computer analysis version 22 according to (Weinberg and Abramowitz, 2008) and (Landau, 2004).

\section{RESULTS AND DISCUSSION}

\section{Effects of Chickpea Seed Extract Foliar Applied on Some Chickpea Growth Characteristics}

The effect of chickpea seed extract was significant on plant height, and branch numbers per plant [Figure 1]. 
The highest chickpea plant reached $(35.23 \mathrm{~cm})$ in control plants and the lowest chickpea plants were $(29.87 \mathrm{~cm})$ when the plants were treated with the highest percent seeds extract, unsprayed chickpea plants with aqueous seeds extract get higher number of branches (8.67 branches. plant $\left.{ }^{-1}\right)$, while foliar extract spraying caused a significant decrease in number of branches in all sprayed plots, especially spraying with $75 \%$ and $100 \%$ which, caused only six branches. plant ${ }^{-1}$. Studying the levels of total chlorophyll before and after spraying of chickpea seed extracts indicated significant differences between percentage levels as shown in Table 1. Before spraying the aqueous extract there were not significant differences between all treatments, while 2 days after spraying there were significant differences between all treatments and it is obvious that the response was percentage dependent wherein all chlorophyll estimations the higher chlorophyll content occurs in control treatments and the lowest chlorophyll content were documented in the highest extract percentage $(100 \%)$. The most important process in plant growth is photosynthesis, so any method for chlorophyll estimation in plant leaves could give an evaluation for plants physiological active processes, in case of low levels of chlorophyll it decreases the rate of carbohydrate production (Richardson et al., 2002). Plant pigments levels are related to physiological stresses, such as allelopathy where, carotenoid increases and chlorophyll decreases (Peñuelas and Filella, 1998).

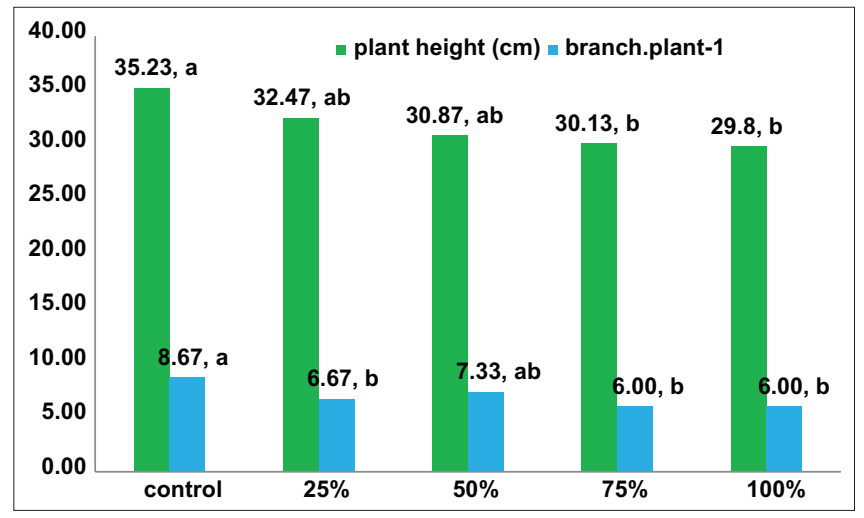

Figure 1: The effect of chickpea seed extract foliar applied on chickpea height and branch number. The same letters indicate no statistically significant difference between the groups according to Duncan Multiple Range Test
Effects of Chickpea Seed Extract Foliar Applied on Chickpea's Yield and Yield Component Characteristics The significant effect of different concentrations of aqueous extracts of chickpea seeds was obvious on all recorded data related to chickpea yield and yield components [Table 2]. The number of pods per plant and number of seeds per pod was at the highest levels (10.33 pods. Plant ${ }^{-1}$ and 1.64 seed. Pod $\left.^{-1}\right)$, respectively, in control treatments while the lowest number of pods and number of seeds per pod (3.33 pods. Plant $\left.{ }^{-1}\right)$ and (1.28 seeds. pod $\left.-^{1}\right)$, respectively, were documented when the highest extract percentage was sprayed. Shoot dry weight was at the peak $(168.00 \mathrm{~g})$ in control treatments where plots sprayed with distilled water while spraying the $100 \%$ percentage of aqueous chickpea seeds extract lowered the shoot dry weight to only $(86.55 \mathrm{~g})$. Seeds yield per plant also was in the highest weight $\left(1.71 \mathrm{~g}\right.$. plant $\left.{ }^{-1}\right)$ in control treatments, but higher percentage caused less seed yield per plant $(0.24 \mathrm{~g}$. plant $\left.^{-1}\right)$. Biological yield per plant recorded the highest yield in control treatments (169.71 g. plant $-^{1}$ ) and the $100 \%$ level caused minimum biological yield of chickpea plants $\left(86.79\right.$ g. plant $\left.{ }^{-1}\right)$. The maximum harvest index was $1.01 \%$ in control treatments and the minimum was $0.30 \%$ when plots were sprayed with $100 \%$ of chickpea seeds aqueous extracts. Hundred seed weight was at the peak in control treatments $(21.19 \mathrm{~g})$ and in $100 \%$ aqueous extracts sprayed plots it was at the lowest level only $(13.77 \mathrm{~g})$. These results indicate that the sprayed aqueous extracts decreased yield and yield components of chickpea and the effect was percent dependent which may be attributed to the allelopathic compounds in chickpea seeds aqueous extracts that affects photosynthetic product partitioning in chickpea yielded seeds (Pooya et al., 2013), also chickpea contains high total phenolic and flavonoid compounds which may act as allelochemicals that inhibit or alter plant metabolism reactions (Almusawi and Alhelfi, 2012).

\section{Effects of Chickpea Seed Extract Foliar Applied on Chickpea Seeds Chemical Characteristics}

The effect of chickpea seeds aqueous extracts foliar applied was significant on nitrogen and protein percentage in seeds chemical characteristic [Table 3] and the highest nitrogen and protein percentage were $3.31 \%$ and $20.70 \%$, respectively, in maximum levels in control treatments while

Table 1: The effect of chickpea seed extract foliar applied on total chlorophyll content of chickpea plants

\begin{tabular}{lccccccccc} 
Extract concentration & \multicolumn{7}{c}{ Chlorophyll measurements } \\
\cline { 2 - 8 } & 1-May & 8-May & 11-May & 14-May & 20-May & 25-May & 30-May & 4-Jun & 9-Jun \\
\hline Control & $70.20^{\mathrm{a}}$ & $73.70^{\mathrm{a}}$ & $75.40^{\mathrm{a}}$ & $74.27^{\mathrm{a}}$ & $71.30^{\mathrm{a}}$ & $64.60^{\mathrm{a}}$ & $59.40^{\mathrm{a}}$ & $58.17^{\mathrm{a}}$ & $43.27^{\mathrm{a}}$ \\
$25 \%$ & $69.72^{\mathrm{a}}$ & $71.30^{\mathrm{b}}$ & $74.00^{\mathrm{a}}$ & $70.67^{\mathrm{b}}$ & $67.43^{\mathrm{b}}$ & $61.47^{\mathrm{a}}$ & $56.63^{\mathrm{ab}}$ & $54.77^{\mathrm{b}}$ & $39.90^{\mathrm{b}}$ \\
$50 \%$ & $69.87^{\mathrm{a}}$ & $69.37^{\mathrm{c}}$ & $72.27^{\mathrm{b}}$ & $69.27^{\mathrm{b}}$ & $65.80^{\mathrm{bc}}$ & $57.40^{\mathrm{b}}$ & $55.33^{\mathrm{b}}$ & $53.20^{\mathrm{b}}$ & $38.40^{\mathrm{b}}$ \\
$75 \%$ & $66.40^{\mathrm{a}}$ & $68.00^{\mathrm{c}}$ & $71.47^{\mathrm{b}}$ & $68.63^{\mathrm{bc}}$ & $64.47^{\mathrm{cd}}$ & $53.37^{\mathrm{c}}$ & $50.57^{\mathrm{c}}$ & $48.90^{\mathrm{c}}$ & $33.57^{\mathrm{c}}$ \\
$100 \%$ & $70.37^{\mathrm{a}}$ & $59.33^{\mathrm{c}}$ & $69.13^{\mathrm{c}}$ & $65.93^{\mathrm{c}}$ & $62.77^{\mathrm{d}}$ & $47.53^{\mathrm{d}}$ & $45.83^{\mathrm{d}}$ & $43.83^{\mathrm{d}}$ & $28.83^{\mathrm{d}}$ \\
\hline
\end{tabular}

Means with the same symbols in one column are not significantly different from each other at alpha=0.05\% based on Duncan Multiple Range Test 
Table 2: The effect of chickpea seed extract foliar applied on chickpea's yield and yield component characteristics

\begin{tabular}{lccccccc}
$\begin{array}{l}\text { Extract } \\
\text { concentration }\end{array}$ & Pods. plant ${ }^{-1}$ & Seed. Pod ${ }^{-1}$ & $\begin{array}{c}\text { Shoot dry } \\
\text { weight }(\mathrm{g})\end{array}$ & $\begin{array}{c}\text { Seed. } \\
\text { plant }{ }^{-1}(\mathrm{~g})\end{array}$ & $\begin{array}{c}\text { Biological } \\
\text { yield. plant }{ }^{-1}(\mathrm{~g})\end{array}$ & $\begin{array}{c}\text { Harvest } \\
\text { index\% }\end{array}$ & $\begin{array}{c}\text { Hundred seed } \\
\text { weight }(\mathbf{g})\end{array}$ \\
\hline Control & $10.33^{\mathrm{a}}$ & $1.64^{\mathrm{a}}$ & $168.00^{\mathrm{a}}$ & $1.71^{\mathrm{a}}$ & $169.71^{\mathrm{a}}$ & $1.01^{\mathrm{a}}$ & $21.19^{\mathrm{a}}$ \\
$25 \%$ & $7.67^{\mathrm{b}}$ & $1.51^{\mathrm{b}}$ & $130.88^{\mathrm{b}}$ & $0.90^{\mathrm{b}}$ & $131.78^{\mathrm{b}}$ & $0.69^{\mathrm{b}}$ & $18.17^{\mathrm{b}}$ \\
$50 \%$ & $6.33^{\mathrm{b}}$ & $1.44^{\mathrm{c}}$ & $88.10^{\mathrm{c}}$ & $0.70^{\mathrm{c}}$ & $88.80^{\mathrm{c}}$ & $0.83^{\mathrm{ab}}$ & $17.34^{\mathrm{b}}$ \\
$75 \%$ & $4.67^{\mathrm{c}}$ & $1.37^{\mathrm{d}}$ & $87.74^{\mathrm{c}}$ & $0.51^{\mathrm{d}}$ & $88.25^{\mathrm{c}}$ & $0.58^{\mathrm{bc}}$ & $15.59^{\mathrm{bc}}$ \\
$100 \%$ & $3.33^{\mathrm{c}}$ & $1.28^{\mathrm{e}}$ & $86.55^{\mathrm{c}}$ & $0.24^{\mathrm{e}}$ & $86.79^{\mathrm{c}}$ & $0.30^{\mathrm{c}}$ & $13.77^{\mathrm{c}}$ \\
\hline
\end{tabular}

Means with the same symbols in one column are not significantly different from each other at alpha=0.05\% based on Duncan Multiple Range Test

Table 3: The effect of chickpea seed extract foliar applied on chickpea seeds chemical characteristics

\begin{tabular}{lcccc}
\hline Extract concentration & Nitrogen $\%$ & Protein $\%$ & Phosphorus \% & Potassium \% \\
\hline Control & $3.31^{\mathrm{a}}$ & $20.70^{\mathrm{a}}$ & $0.42^{\mathrm{a}}$ & 0.04 \\
$25 \%$ & $3.08^{\mathrm{b}}$ & $19.27^{\mathrm{b}}$ & $0.42^{\mathrm{ab}}$ & 0.04 \\
$50 \%$ & $2.90^{\mathrm{bc}}$ & $18.12^{\mathrm{bc}}$ & $0.40^{\mathrm{bc}}$ & 0.04 \\
$75 \%$ & $2.72^{\text {cd }}$ & $17.03^{\text {cd }}$ & $0.38^{\mathrm{c}}$ & 0.04 \\
$100 \%$ & $2.65^{\mathrm{d}}$ & $16.55^{\mathrm{d}}$ & $0.30^{\mathrm{d}}$ & \\
\hline
\end{tabular}

Means with the same symbols in one column are not significantly different from each other at alpha=0.05\% based on Duncan Multiple Range Test

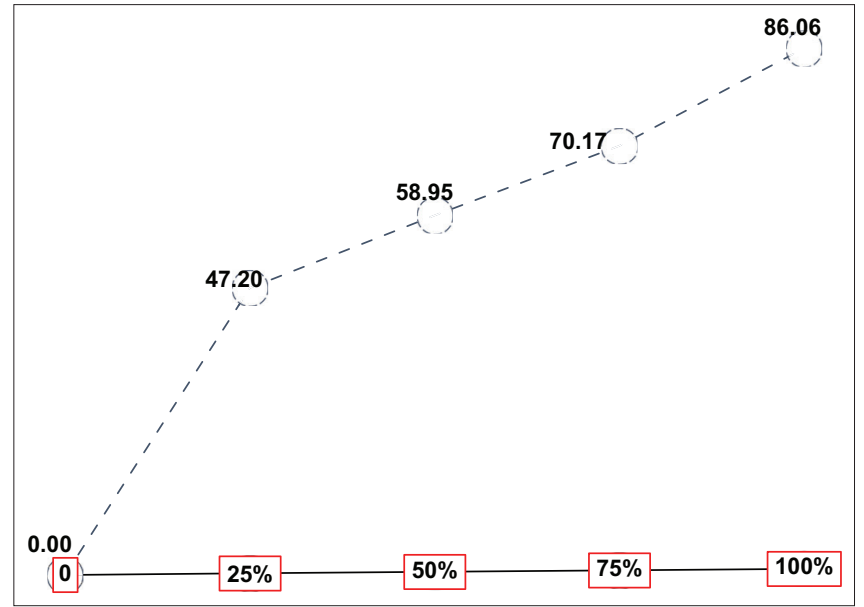

Figure 2: The effect of chickpea seed extracts different percentages foliar applied on Allelopathic Index

the lowest values were $2.65 \%$ and $16.55 \%$ in $100 \%$ extracts sprayed plots. Phosphorus percentage differed significantly under the extract spray and the peak of phosphorus percentage was $0.42 \%$ in control treatments and the lowest value was $0.30 \%$ when the plots sprayed with $100 \%$ extract percentage. The effect of different percentages of chickpea aqueous extracts was not significant on potassium percentage in chickpea seeds. The allelopathic effect on nitrogen and protein percentage in chickpea seeds could be attributed to polyphenolic compounds that inhibit seed germination, growth, nitrogen uptake, and minimize the activity of nitrogenase in nodulated chickpea roots (Ishii-Iwamoto et al., 2006). Allelochemicals prevent the phosphorus supply of the recipient plants so finally it will lower phosphorus content in yield (Zhou and Yu, 2006).

\section{Effects of Chickpea Seed Extract Foliar Applied on Allelopathic Index}

Allelopathic index was estimated according to equation (2) based on chickpea seed yield, the effect was percentage dependent as shown in Figure 2, where the highest allelopathic index was $86.06 \%$ when chickpea pots sprayed with 100\% extract, from the figure it was obvious that the chickpea seed extracts negatively inhibited growth and yield of its own species (Jefferson and Pennacchio, 2003; Wardle et al., 1991).

\section{CONCLUSIONS}

Chickpea aqueous extracts when foliar sprayed for three successive days imposed allelopathic impact on its own species and inhibited growth, lowered yield, and yield components. This may indicate the potentiality of chickpea extracts to act as bio-herbicides on different weed plants, so experiments needed in this area to clarify this potentiality.

\section{REFERENCES}

Ali, K. A. 2020. Allelopathy index: A new mathematical assessment method for allelopathy studies. Zanco J. Pure Appl. Sci. 33(2): 1-18.

Allen, S. E., H. M. Grimshaw, J. A. Parkinson and C. Quarmby. 1974. Chemical Analysis of Ecological Materials. Blackwell Scientific Publications, Oxford, United Kingdom.

Almusawi, U. A. H. and S. A. H. Alhelfi. 2012. Isolation, identification and determination the antioxidant activity of phenolic compound to some plants extracts. Karbala Univ. J. $2^{\text {nd }}$ Agricultural College Scientific Conference: 1218-1228.

Al-Taee, A. H. M. and M. A. Al-Nori. 2015. Effect of sowing dates and plant popualtion on yield and some seed quality of local chickpea (Cicer arietinum). J. Kirkuk Univ. Agric. Sci. 6: 103-116.

Ashti, S., F. Hero, A. Dlshad and A. Nawroz. 2018. Response of some plant species towards the allelopathy of two types of chickpea (Cicer arietinum L.) seed extracts. Appl. Ecol. Environ. Res. 16: 8119-8129.

Chai, Q., G. Huang, P. Huang, E. Zhang and F. Feng. 2005. Identification of Cicer arietinum root exudation and allelopathy of benzaldhyde. Acta Prataculturae Sin. 14: 106-111.

Chaichi, M. R. and L. Edalati-Fard. 2005. Evaluation of allelopathic 
effects of chickpea root extracts on germination and early growth of sorghum (Sorghum halepense), soybean (Glycine max L.) and sunflower (Helianthus annus). J. Crop Prod. 4: 247-255

Doruchowski, G., R. Hołownicki, A. Godyń and W. Świechowski. 2012. Sprayer Calibration Training Concept and Performance. $4^{\text {th }}$ European Workshop on Standardised Procedure for the Inspection of sprayers, SPISE, 2012, Citeseer. p27-29.

Duke, S. O. 2003. Ecophysiological aspects of allelopathy. Planta. 217: 529-539.

Einhellig, F. A. 1995. Mechanism of Action of Allelochemicals in Allelopathy. ACS Publications, Washington, DC.

El-Adawy, T. A. 2002. Nutritional composition and antinutritional factors of chickpeas (Cicer arietinum L.) undergoing different cooking methods and germination. Plant Foods Hum. Nutr. 57: 83-97.

Hay, R. 1995. Harvest index: A review of its use in plant breeding and crop physiology. Ann. Appl. Biol. 126: 197-216.

Ishii-Iwamoto, E., D. Abrahim., M. Sert., C. Bonato., A. Kelmer-Bracht and A. Bracht. 2006. Mitochondria as a site of allelochemical action. In: Allelopathy. Springer, Berlin, Heidelberg.

Jefferson, L. and M. Pennacchio. 2003. Allelopathic effects of foliage extracts from four Chenopodiaceae species on seed germination. J. Arid Environ. 55: 275-285.

Joshi, P. K., P. P. Rao, C. Gowda, R. B. Jones, S. N. Silim, K. Saxena and J. Kumar. 2001. The World Chickpea and Pigeonpea Economies Facts, Trends, and Outlook. International Crops Research Institute for the Semi-Arid Tropics.

Khalil, A. W., A. Zeb, F. Mahmood, S. Tariq, A. B. Khattak and H. Shah. 2007. Comparison of sprout quality characteristics of desi and kabuli type chickpea cultivars (Cicer arietinum L.). LWT Food Sci. Technol. 40: 937-945.

Landau, S. 2004. A Handbook of Statistical Analyses Using SPSS. CRC Press, Boca Raton, Florida.

Larew, H. G., J. Knodel-Montz, R. E. Webb and D. J. Warthen. 1985. Liriomyza trifolii (Burgess) (Diptera: Agromyzidae) control on chrysanthemum by neem seed extract applied to soil. J. Econ.
Entomol. 78: 80-84.

Liu, Y. H., R. S. Zeng, M. An, A. U. Mallik and S. M. Luo. 2008. Autotoxicity in agriculture and forestry. In: Allelopathy in Sustainable Agriculture and Forestry. Springer, Berlin, Heidelberg.

Mushtaq, W., M. B. Siddiqui and K. R. Hakeem. 2020. Allelopathy: Potential for Green Agriculture. Springer Nature, Berlin, Heidelberg.

Peñuelas, J. and I. Filella. 1998. Visible and near-infrared reflectance techniques for diagnosing plant physiological status. Trends Plant Sci. 3: 151-156.

Pooya, E. S., S. Tokasi, M. T. Alebrahim and E. Kazerooni. 2013. The inhibitory or stimulatory effects of chickpea cultivars extracts on germination and growth of sunflower and maize. Int. J. Agron. Plant Prod. 4: 1148-1157.

Richardson, A. D., S. P. Duigan and G. P. Berlyn. 2002. An evaluation of noninvasive methods to estimate foliar chlorophyll content. New Phytol. 153: 185-194.

Wardle, D., M. Ahmed and K. Nicholson. 1991. Allelopathic influence of nodding thistle (Carduus nutans L.) seeds on germination and radicle growth of pasture plants. New Zealand J. Agric. Res. 34: 185-191.

Weinberg, S. L. and S. K. Abramowitz. 2008. Statistics Using SPSS: An Integrative Approach., Cambridge University Press, Cambridge.

Wood, J. and M. Grusak. 2007. Nutritional value of chickpea. In: Chickpea Breeding and Management. CABI publications, USA. p101-142.

Yasmin, S., B. Saleem and A. Irshad. 1999. Allelopathic effects of aqueous extract of chickpea (Cicer arietinum) and wheat (Triticum aestivum L.) on each other's growth and quality. Int. J. Agric. Biol. 1: 110-111.

Zhou, Y. and J. Yu. 2006. Allelochemicals and photosynthesis. In: Allelopathy. Springer., Berlin, Heidelberg.

Zhu, J., N. Tremblay and Y. Liang. 2012. Comparing SPAD and atLEAF values for chlorophyll assessment in crop species. Can. J. Soil Sci. 92: 645-648. 